\title{
TURKISH FOREIGN POLICY AT THE END OF THE COLD WAR: ROOTS AND DYNAMICS ${ }^{1}$
}

\author{
MUSTAFA AYDIN
}

\begin{abstract}
Starting with the military coup d'état of September 12, 1980, Turkey had experienced fundamental changes in its political structure, economic system, social strata, cultural patterns, religious expressionism, and foreign policy. With the end of the Cold War ten years after, the world entered a period of historic systemic changes. Along the way, Turkey moved suddenly from a staunchly pro-western isolationist existence in its immediate neighbourhood into a central posture with an intention to have an effect across a vast region extending 'from eastern Europe to western China'. This change in Turkey's stance and mentality was due to wider changes experienced within and around Turkey during the 1980s. This paper, employing theoretic and practical explanations, explores Turkey's transformation in domestic and foreign policies during the 1980s and early 1990s, in order to set the stage to the analysis of Turkish foreign policy at the end of the Cold War. It will specifically look at the nature of the political regime, socio-economic dynamics, and external environment as factors that brought about change in Turkish foreign policy in the wake of the end of the Cold War.
\end{abstract}

\section{KEYWORDS}

Turkish Foreign Policy, Change, Foreign Policy Analysis, Determining Factors, Coup D'état, International Setting, Economic Structure, Decision-Making System.

\footnotetext{
${ }^{1}$ This is a follow-up work to my two previous papers, in an attempt to determine the various factors that shape Turkish foreign policy in the $20^{\text {th }}$ century. What I have termed as 'structural determinants' of Turkish foreign policy, were examined in 'Determinants of Turkish Foreign Policy-I: Historical Framework and Traditional Inputs', Middle Eastern Studies, Vol. 35, No. 4 (October 1999), pp. 152-186; and 'conjunctural factors' in 'Determinants of Turkish Foreign Policy II: Changing Patterns and Conjunctures During the Cold War', Middle Eastern Studies, Vol. 36, No. 1 (January 2000), pp. 103-139. This paper will update them and look at 1980s, during which Turkey experienced important changes that largely affected its foreign policy since then.
} 


\section{INTRODUCTION AND ANALYTICAL FRAMEWORK}

Dramatic changes in world politics that accompanied the end of the Cold War, though was greatly welcomed, have not yet provided for the anticipated arrival of an unprecedented era of peace, stability and democracy. Initial euphoria and optimism is now replaced by extremely intractable problems and difficult policy choices that have emerged. While the international society proved to be ill prepared and too slow to successfully deal with the multitude of threats and problems, the 'change' (be it political, economic, social, or systemic) has become a constant feature of international politics.

Amidst the historic systemic changes, Turkey, once a distant outpost of NATO on the European periphery, moved to the centre of the problematic post-Cold War world politics. She stood surrounded by 13 of the 16 threat generating regions, identified by NATO at the end of the Cold War. Yet, from a staunchly pro-western isolationist existence in its immediate neighbourhood, Turkey, at the end of the Cold War, suddenly moved into a posture, intended to have an effect across a vast region extending "from eastern Europe to western China'. ${ }^{2}$ This change in Turkey's stance and mentality was not accidental, but due to wider changes experienced within and around Turkey during the 1980s. Without denying the importance of the momentum provided by the end of the Cold War, this paper aims to explore Turkey's transformation in domestic and foreign policies during the 1980s and early 1990s, in order to discern developments behind the powerful impetus in Turkey at the end of the Cold War to grab emerging opportunities. While doing this, Turkish experience would be juxtaposed against the wisdom from the theory of foreign policy analysis, in an effort to enhance attempts to sketch out a theoretical framework for Turkish foreign policy.

Constant transformation was one of the unchanging consistencies of Turkish socio-political life during the 1980s. Starting

${ }^{2}$ For earlier analyses of Turkey's newly-found self-reliance on foreign policy at the end of the Cold War see M. Aydin, 'Turkey and Central Asia; Challenges of Change', Central Asian Survey, 15, No. 2 (1996), pp. 157177; S. S. Gurel and Y. Kimura, Turkey in a Changing World (Tokyo, 1993); and G. Fuller and I. O. Lesser, Turkey's New Geopolitics; From the Balkans to Western China (London, 1993). 
with the military coup d'état of September 12, 1980, Turkey had experienced fundamental changes in its political structure, economic system, social strata, cultural patterns, religious expressionism, and foreign policy. As a result, at the end of the decade Turkey was a largely transformed country and the thrust for change was still visible. The transformation of various aspects of Turkish foreign policy may not be discernible all the time for outsiders and the changes may not always be as momentous as we witnessed at the end of the Cold War across Europe and the former Soviet Union, but it has nevertheless been there.

According to Zinnes change implies that 'something is happening through time' and that 'what was true at one point is different at a subsequent time point' ${ }^{3}$ In this sense, 'change' has become one of the truisms of Turkish foreign policy since 1983, when civilian government once again took over power. A change in any policy is usually based on a change in ideas, on rethinking or reappraisal, and a variety of factors may have impact on specific foreign policy reappraisals or changes. ${ }^{4}$ When and what factors determine whether and to what extend pressure for change in policy will in fact produce a change in hitherto rigid policy patterns is an important issue in foreign policy analysis. ${ }^{5}$ In theory, a reappraisal of ideas may occur because of;

-- Changes in the composition of the policy-making system; that is shifts in domestic politics may place new people in positions of power and these new policy-makers may have 'normative, descriptive or theoretical ideas that differ from those of their predecessors', thus leadership change may also imply a policy change. ${ }^{6}$ In this context, throughout the 1980s, first prime minister and later president Turgut Ozal stood out with his 'different' ideas and 'vision' about various aspects of governmental policies, including foreign policy.

${ }^{3}$ D. A. Zinnes, 'Prerequisites for the Study of System Transformation' in O.

R. Holsti. R. M. Siverson and A. L. George (eds.), Change in the International System (Boulder, 1980), p. 16.

${ }^{4} \mathrm{~K}$. Goldman, Change and Stability in Foreign Policy; The Problems and Possibilities (New York, London, 1988), p. 1.

5 Ibid., p. 3.

${ }^{6}$ Ibid., p. 12. 
-- Changes in the balance of power within the policy-making system; that is if the policy-making system contains advocates of competing policies, the balance of power between the camps may determine which policy will be pursued. ${ }^{7}$ The struggle between the top decision-making bodies over Turkey's policy during the Gulf War of 1990-1991 is a good example of this.

- Changes in environmental circumstances may bring about foreign policy reappraisals. International system and the relationship between the state and conditions existent within that system determines how the state would behave ${ }^{8}$ Moreover, 'nations under pressure adapt to changing conditions in their environment' ${ }^{9}$ Thus, systemic changes may generate an important impetus for change by altering the conditions for foreign policy. ${ }^{10}$ In this context, the end of the Cold War and the subsequent transformation of world politics provided important momentum for national policy changes. System transformations may also involve the extension of new, or abandonment of previous, commitments and therefore signify a change in the goals and/or objectives of participating actors. ${ }^{11}$ Turkey's new commitments during the 1980s towards the Black Sea Economic Cooperation Region (later Organization - BSEC), transformation of the Regional Cooperation for Development (RCD) to the Economic Cooperation Organization (ECO), and relations with the European Community (later the European Union-EU) constitute ample examples.

${ }^{7}$ Ibid., p. 13.

${ }^{8}$ W. D. Coplin, Introduction to International Politics: A Theoretical Overview (Chicago, 1971), p. 140.

${ }^{9}$ Goldman, op. cit., p. 4.

${ }^{10} \mathrm{~L}$. Lindberg, and S. Scheingold, Europe's Would-be Polity: Patterns of Change in the EC (Englewood Cliffs, N.J., 1970), pp. 137-138, argued that external factors play a greater role in system transformation then they do in the other change processes.

${ }^{11} \mathrm{~S}$. Genco, 'Integration Theory and System Change in Western Europe: The Neglected Role of System Transformation Episodes' in Holsti/Siverson/George, op. cit., p. 68. 
Nations also take into account the way in which the international environment responds to their policies. Accordingly, the 'spill-back process' or the 'negative feedback' from the international environment may also create pressures for change. ${ }^{12}$ Hence, the questions of whether western pressure had an impact on Turkey's democratisation-human rights policies, and whether the negative feedback Turkey received from European countries and organizations after the 1980 coup d'état forced it to look for new areas of linkage, are particularly interesting.

While the first two possible determinants of change are related to the internal domain, the latter is to the international. Since the governments formulate foreign policy in the context of domestic as well as international pressures, foreign policy studies should involve an understanding of both domestic and external environments and the interaction between the two. ${ }^{13}$ Thus, the institutional structure, i.e., the type of political and economic regimes, by which governments make and implement their foreign policies, is also important. ${ }^{14}$ Finally, linkages between national and international systems continually reinforce each other, ${ }^{15}$ and the impact of any action in international politics 'on a polity will vary according to particular nations, structures and groups to which the polity is linked and the nature of that link. Nations do not react to the international system as a whole, but to the way it is reflected in particular actors with whom they have most contact'. ${ }^{16}$ In connection with this, Turkey's vocational linkages with the West in general and especially the effects of European criticism and Turkish responses are important.

\footnotetext{
${ }^{12}$ Goldman, op. cit., p. 4.

${ }^{13}$ W. Wallace, Foreign Policy and the Political Process (London, 1971), p. 12; P. A. Reynolds, An Introduction to International Relations, $3^{\text {rd }}$ ed. (London, New York, 1994), p. 54; J. N. Rosenau, 'Introduction: Political Science in a Shrinking World' in J. N. Rosenau (ed.), Linkage Politics: Essays on the Convergence of National and International Systems (New York, 1969), p. 7.

${ }^{14}$ Wallace, op. cit., p. 12; K. J. Holsti, International Politics: A Framework for Analysis, 3rd ed. (Englewood Cliffs, N.J., 1977), p. 108.

${ }^{15}$ Rosenau, op. cit., p. 7.

${ }^{16}$ D. A. Chalmers, 'Developing on the Periphery: External Factors in Latin American Politics', in Rosenau (ed.), op. cit., p. 69.
} 
This paper, in the context of changes and linkages, will look at various factors that brought about changes in Turkish foreign policy right about the time the world, too, was experiencing historic changes. Needless to say, one of this study's principal contentions is that the type of political and economic regime in a state can be crucial in determining its foreign policy. Further, domestic environment and foreign policy of a country are intimately related and that each serves better to explain and shed light upon the other. Hence, it will show that the peculiarities of the Turkish governing system, its chosen economic strategy, and the 'Turkish style of democracy' have all had important effects on determining its foreign policy on the eve of the momentous changes in world politics and the end of the Cold War.

With these general observations in mind we may suggest a working proposition of the following factors as contributing to Turkish foreign policy formulation during the period under consideration (1980-1991): 1) the nature of the domestic political regime, including balance of power within, and composition of, the policy-making system; 2) Socio-Economic dynamics; and 3) External environment.

\section{NATURE OF THE REGIME AND FOREIGN POLICY}

\section{In Theory}

Domestic issues have important bearing on formulation and substance of foreign policy, though the extent and nature of this influence varies with nation's political system. ${ }^{17}$ There are differences between parliamentary democracies; guided democracies -of which Turkey was an example during the second half of 1980s; authoritarian governments -as the military regime of 1980-1983 could be categorized; and totalitarian regimes. In democracies for example, the government has to contend with political parties, differing interests, traditions, ethics, religion, and a multitude of other pressures.

${ }^{17} \mathrm{~K}$. London, The Making of Foreign Policy: East and West (New York, 1965), p. 56. 
The political system of a country is also significant in terms of the decision-making process and responsibilities, as it determines powers, focus and the mechanisms of decisions in foreign policy. ${ }^{18}$ Democracies have their constitutional provisions for the organization of international affairs. Though there may be some manoeuvrability within constitutional framework, fundamentally whoever is in power must conform to it. These provisions sometimes render policy formulation and implementation cumbersome except in emergency when the nation closes ranks behind its leaders. ${ }^{19}$ Nonetheless, parliamentary supervision remains active; and as the parliamentarians are rarely agree on vital issues, it may take too long to get an agreement on any given subject, tempting policy-makers to by-pass the parliament. ${ }^{20}$

Dictatorships, on the other hand, permit decision-making without the supervision of parliamentary bodies. The fact that in a dictatorship a foreign policy decision is made secretly, without controls and restrained, contributes to the speed of decisions and swift action. In a democracy, on the other hand, foreign policy decisions are made as a part of public, parliamentary debate; their enforcement is slower and subject to moral restraints. ${ }^{21}$ This brings us to the much-debated question of the role of public opinion in international affairs and foreign policy. The general assumption is that, in democracies, public opinion exerts considerable influence on policy-makers. It is argued, on the other hand, that public opinion offers abundant criticism but rarely, if ever, has constructive advice. ${ }^{22}$ Moreover, irrational ideologies and charismatic leaders may sway the masses. Therefore, not institutions alone, but institutional behaviour is also relevant as the democratic and non-democratic way of life is mirrored in institutional behaviour, attitudes towards institutions, and techniques of adjustments.

\footnotetext{
${ }^{18}$ F. Gros, Foreign Policy Analysis (New York, 1954), p. 118.

${ }^{19}$ London, op. cit., p. 58.

${ }^{20}$ Ibid., p. 59.

${ }^{21}$ J. N. Rosenau, 'Study of Foreign Policy' in J. N. Rosenau, K. W. Thompson and G. Boyds (eds.), World Politics: An Introduction (New York, 1971), p. 25.

${ }^{22}$ London, op. cit., p. 61.
} 
Without denying the importance of other factors, the actual choices of policies within states are determined to a considerable degree by the interpretation of the environment by the leaders and their conception of alternatives. Decision-makers' understanding of the nature of their choices in turn depends on many factors, including their experience while rising to eminence, the structure in which they must operate, and the values of their society. In this context, the personality of leaders, who control the focus of power, may have important influences on foreign policy. This is especially important in authoritarian regimes, in which power of dictators is not restrained by democratic bodies, and where they exercise decisive influence over the conduct of foreign policy. ${ }^{23}$

In the modern world, the political leadership in most societies acts in order to maintain the security of their national state: ${ }^{24}$ so much so that foreign and security policies have merged to the point where statesmen and military strategists must collaborate closely. ${ }^{25}$ Therefore, it goes without saying that military leaders are needed for expert advice, and it is possible that their considered opinion can strongly influence policy decisions. However, it is the responsibility of the decision-makers to determine 'how much influence the military may be permitted to exert on foreign policy decisions and whether military personnel should be permitted to state conflicting views in public'. ${ }^{26}$ Whether the influence of military leaders can be kept within bounds by a civilian government will always be crucial to a nation's position in international affairs and to its internal politics. Since Turkey was ruled by a military regime during 1980-1983, and the military was effective in policy choices even after 1983, the civilmilitary relationship and its effect on foreign policy-making are important aspects of this paper.

Analysts do not normally regard military regimes as a variable in foreign policy studies. However, at least one study has showed that

${ }^{23}$ Gros, op. cit., p. 123.

${ }^{24}$ R. C. Macridis and K. W. Thompson, 'The Comparative Study of Foreign Policy' in R. C. Macridis (ed.), Foreign Policy in World Politics, $2^{\text {nd }}$ ed. (Englewood Cliffs, 1962), p. 12.

${ }^{25}$ London, op. cit., p. 73.

${ }^{26}$ Ibid., pp. 100-101. 
there appear some similarities between military regimes' attitudes to national security and foreign policy issues. ${ }^{27}$ Two hypotheses are especially relevant for the Turkish case. First, observing that orientations and attitudes of military personnel towards the political activity are clearly different from those of the civilian politicians, we can assume that armed forces personnel, whose main preoccupation is to defend the country, 'perceive national interest and the means to effectively serve it differently', and as such 'it is reasonable (...) to expect that once they come to power (...) the country's foreign policy undergoes a change'. ${ }^{28}$ Secondly, observing that civilian influences on key policy-making units are replaced by the military after coups, and that the military regimes usually restrict, if not totally prevent, 'the participation of hitherto influential groups in the decision-making process', it can be argued that this change in the decision-making process would affect the regime's structure, which is 'one of the important determinants of the country's foreign policy', thus it is 'reasonable to expect that the transformation of a civilian regime into a military one affects a country's foreign policy'29

\section{In Practice}

During the 1980s, Turkey passed through different regimes: The decade started with a period of multi-party democracy, entrapped by mounting terrorism and rampant economic disasters, which was abruptly interrupted by the September 12 coup d'état. What followed were three years of direct military rule and a transitional period that finally gave way once again to a multi-party parliament, if not full democracy. Thus, from the outset, it might seem that Turkish politics ended the decade where it had originally started. However, the Turkey of December 3, 1990, when the Chief of Staff, General Torumtay, resigned because the governing framework at the top clashed with his 'principles and understanding of what the state

${ }^{27} \mathrm{P}$. Parakala, Military Regimes, Security Doctrines, and Foreign Policy: Brazil, Indonesia, and Ghana, PhD Thesis, University of London, 1991.

${ }^{28}$ Ibid., p. 7.

${ }^{29}$ Ibid., p. 8. 
should be', ${ }^{30}$ or the Turkey of February 28,1997 , when the Generals, who thought that the survival of the Turkish state was at stake, choose to work within the system cooperating with the President and the Prime Minister through the National Security Council, were fundamentally different from that of September 12, 1980, when the then Chief of General Staff, General Evren, led a junta to dislodge the elected government because 'the state had been rendered unable to function (...) and the political parties have failed to bring about unity and togetherness' ${ }^{31}$

The difference between these actions is important because the September 12 coup and the developments following it were immensely important for Turkey's external relations, especially with European democracies. In general terms, the nature of the political regime of a country and its composition affects its foreign policy for mainly two reasons. ${ }^{32}$ Firstly, the political regime has the power to define the broader framework of country's overall political philosophy, which, in the final analysis, constrains, if not conditions, its choices in international arena, since it determines how the regime sees itself vis-à-vis other regimes and states. Secondly, the nature of political regime in a country also creates images outside the country and any change in the 'established' political regime of a country tends to attract reactions from other countries, which might result in pressures for change. ${ }^{33}$

The frequency of abundant military takeovers in Turkey indicates the important role the army plays in Turkish political life. For all that, however, Turkey has been considered in the same league with military dictatorships, at worst, or with guided democracies, at best. In particular during the period 1980-1983, Turkey was under a

${ }^{30}$ Quoted from the resignation letter of the Chief of General Staff, General Torumtay, by 'Military Chief Resigns', Facts on File, 14 December 1990, p. 935 .

31 'Military Communiqué No. 1', text in General Secretariat of the National Security Council, 12 September in Turkey; Before and After (Ankara, 1982), p. 221.

${ }^{32}$ D. B. Sezer, 'Turkish Foreign Policy in the Year 2000' in Turkish Political Science Association, Turkey in the Yea 2000 (Ankara, 1989), p. 65.

${ }^{33}$ Goldman, op. cit., p. 4. 
full military regime, though one can differentiate it from other military regimes in various points. ${ }^{34}$ Its officially proclaimed aim was to guide the country into a full democracy as is understood in the west. However, in practice, democratic identity was denied to Turkey, both under the military regime and during the subsequent transition period (1983-1987) by a combination of factors, ranging from continued restrictions on fundamental rights and freedoms to explicit (implicit for the post-1983 period) usage of military's control and authority on various aspects of sociao-political life.

Not surprisingly, being less than a full democracy created tensions for Turkey during the 1980s, not only in domestic politics but in foreign policy, too. Since the military regime up until 1983, or the quasi-democracy thereafter, clearly contradicted with the fundamental values of Western Europe, with which Turkey endeavoured to identify itself, it created tensions for Turkish foreign ministry where it seemed to matter most. As a result, Turkish foreign policy had to operate under strain as the military regime in Turkey attempted to 'reconcile the divergent objectives of moving towards integration with Western Europe while defending the rationale of being less than a full democratic regime', ${ }^{35}$

In a more general sense, the frequency of military regimes in recent Turkish political history, together with a general tendency toward the suppression of certain ideas and freedoms, have become impediments for Turkey in its overall relations with the west. Such practices, especially the Turkish human rights record, have been instrumental in creating a general lack of sympathy for Turkey in western public opinion. ${ }^{36}$ As a result, being governed by a military

${ }^{34}$ For differences of the Turkish military from other interventionist armies, see A. Kemal, 'Military Rule and the Future of Democracy in Turkey', Merip Reports, March/April 1984; W. Hale, 'Transition to Civilian Governments in Turkey; the Military Perspective' in M. Heper and A. Evin (eds.), The State, Democracy and the Military; Turkey in the 1980s (Berlin, New York, 1988), pp. 160-165; D. A. Rustow, 'The Middle Eastern Society And Politics' in S. N. Fisher (ed.), The Military in the Middle East (Columbus, 1963).

${ }^{35}$ Sezer, op. cit., p. 66.

${ }^{36} \mathrm{P}$. Robins, 'The Overlord State: Turkish Policy and The Kurdish Issue', International Affairs, Vol. 69, No. 4 (1993), pp. 292-293; Sezer, ibid. 
dictatorship or a transitional democracy at best during the 1980 s circumscribed Turkey's options in the international arena and put constraints on its already existing relationships. This was especially evident in Turkey's relations with western European countries, mainly because of the nature of its existing linkage patterns with them. Particularly, those countries which were non-committal in their early reactions towards the coup gradually became hostile towards it because of what they perceived as the impossibility of condoning a military dictatorship, with its deteriorating human rights record and torture allegations, and especially of accepting it to the European 'democratic club'. ${ }^{37}$ On the other hand, due to the presence of a linkage area between Turkey and Europe, the European governments chose to apply pressure to Turkey instead of pushing her out of the European system, and thereby their influence area. However, the 'ever-lasting' foreign (read: European) pressure created a counterreaction in Turkey, forcing her at times to look for alternative options to Europe.

On the other hand, the nature of the political system gained meaning primarily in the context of Turkey's European vocation as external pressures are only effective so long as the subject state is receptive to them. It is clear that the internationalisation of Turkey's domestic politics has created a constant restraint on governments, and as such had effects both on the country's domestic political evaluation and on its foreign policy/relations. The crucial factor in this connection has been Turkey's receptivity towards external, i.e. European, pressures due to the existence of its political, economic, and ideological linkages with Europe. While these linkages enabled Europeans to pressure Turkey on certain aspects of its internal politics, especially about human rights and democratisation, Turkey's own identification with Europe made it susceptible and responsive to such pressures. Approached from this angle, it becomes easier to understand why successive Turkish governments reacted harshly when faced with European criticism, and why they attributed such

${ }^{37}$ The military regime expressed its decision to apply fro full membership in the then European Communities once Turkey returned to democracy, recognizing the connection as early as 1981 between democratization and the gaining membership in the EC/EU. The decision opened the way for legitimate Euro-scrutiny and criticism of the regimes' practices that in turn generated reactions from the generals. 
importance to the opinions of an otherwise marginal European organisation, i.e. the Council of Europe. Turkey's membership of the Council was at the time the only institutionalised proof of its 'Europeanness'; and ideological and 'identificational' linkages of the Turkish westernising elite demanded being part of Europe.

The strength and importance of Turkey's linkages with Western Europe was amply demonstrated by the fact that even during the worst period of European criticisms, the Turkish leadership chose to stay and faced the criticisms instead of taking the country out of European realm. Thus, during the 1980s, European attempts to influence were strongly felt in Turkey and, whatever the political rhetoric to the contrary, were responded to. Although this response usually manifested itself in publicly defiant attitudes, most of the time the governments were quietly engaged in diplomatic and propaganda campaigns in western states, both to 'explain' Turkey's policies and to curtail further public criticisms, as well as reforms inside Turkey. Thus 'Europeanization' of Turkey helped its further democratization as well.

In the process, however, Turkish foreign policy, especially visà-vis Western Europe, became dependent both on domestic political developments and on European reactions to them. The latter, in turn, was an important input in determining domestic political developments. Although it is difficult to ascertain the exact proportion of the effectiveness of European pressures on Turkey's democratisation process, it is pretty clear that Turkey's 'western vocation' and its long history of westernisation affected this transition to a considerable extent. ${ }^{38}$ During the process, however, Turkey and

${ }^{38}$ For similar views see, Hale, op. cit., pp. 161-162; U. Steinbach, 'Turkey's Third Republic', Aussenpolitik (English Edition), Vol. 19, No. 3 (1988), p. 248. For opposing views see E. Ozbudun, 'Development of Democratic Government in Turkey: Crises, Interruptions and Re-equilibrations' in E. Ozbudun (ed.), Perspectives on Democracy in Turkey (Ankara, 1988), p. 45; and I. Turan, 'The Evolution of Political Culture in Turkey' in A. Evin (ed.), Modern Turkey: Continuity and Change (Leske, 1984), p. 55. Both emphasised the importance of the existence of Turkish democratic political culture and downplayed the role of external factors in determining Turkey's political regime. They also argued that foreign pressures were usually counter-productive. 
the Europe grew apart, both because of the Turks disappointment with the Europeans who 'let them down in their hour of need' and the considerable coolness of European public opinion towards Turkey, created by what appeared as yet another demonstration of the inability to sustain a workable democracy that built up its 'otherness'.

It was stated earlier that a critical international environment might create pressures on a country for reappraisal of its hitherto followed policies. In Turkish case, the external criticisms and hostile international, i.e. European, environment was instrumental after 1980 in forcing its decision-makers to look for alternative connections, which led to Turkey's openings towards the Middle East and former Eastern Block countries. This do not denies the role of domestic actors, internal factors, and systemic changes in reformulation of Turkish foreign policy, but the emphasis here, in contrast to the official Turkish view, is on the existence of a linkage pattern between international pressure, domestic politics, and the reappraisal of foreign policy.

In this context, the militarist nature of its government did not affect Turkey's relations with the east European or Middle Eastern countries, which did not raise objections about democracy, or indeed about torture allegations or human rights abuses in the country. In fact, Saudi Arabia was the first state to congratulate the Turkish military administration, and others followed suit. ${ }^{39}$ Unlike European organizations, the Organization of the Islamic Conference (OIC) did not send human rights delegations to Turkey to tour prisons and talk to dissidents. For that matter, the change of the regime did not affect Turkey's relations with the US either, whose considerations for human rights and democracy were suppressed by its strategic interests in the Middle East after the developments of 1979 and 1980. Therefore, while Turkey's relations with Western Europe, which felt unable to understand the rationale behind the continued level of military intervention, were souring; its relations with the Middle Eastern countries, Eastern Block and the US, who gave a supportive shoulder, were improved. Turkey's search for alternative courses of

${ }^{39}$ M. Aydin, Foreign Policy Formation and Interaction Between Domestic and International Environments; A Study of Change in Turkish Foreign Policy, 1980-1991, unpublished PhD Thesis, Lancaster University, 1994, p. 120. 
action was reflected by presidential visits during 1982 to Bulgaria, Rumania, Yugoslavia, Hungary, and even China, while no invitations were extended by European governments. It was obvious that while the military government needed the west for political, military and economic support, it could not bear to be forced into a position of isolation, hence attempted to find new openings for Turkey. Moslem world was one of such openings. During the 1980s, the growing political importance of the Middle Eastern states for Turkey and desire to use them as balance against European criticism were increasingly evident in the official speeches. The declaration from General Evren in April 1982 indicated a new direction for Turkey. He affirmed that Turkey was a European country and, at the same time, a Middle Eastern country. ${ }^{40}$ The cooling relations with Western Europe constituted, together with economic necessities, the principal reason for Turkey's new drive toward the Middle East. At a political level, too, Ankara had been striving to break out of its isolation among the countries of the Third World by intensifying its relations with the Moslem world. At this juncture, the sympathetic attitudes of the Islamic states towards the military regime helped Turkey to turn more eagerly towards the East. Together with sharp upsurge in economic relations, Turkey saw the need to assume a more active role in the Middle East. As a result, Kenan Evren became the first Turkish President to attend a meeting of the OIC in January 1984. Turkey also joined the Conference's mediation efforts between Iran and Iraq, and since 1984 has hosted the Economic Development and Cooperation Committee of the IOC. As a result of expanding relations with the Arab world, Turkish-Israeli relations were continuously downplayed during the period. ${ }^{41}$

The nature of the political system also affects the combination and/or structure of policy-making bodies. The 1982 Constitution, prepared by the military regime, gave priority to a strong state and a strong executive within that state, and favoured the president against the cabinet, as reflected in the strong positions taken both by president Evren and later by president Ozal in their relations with

${ }^{40}$ P. Henze, 'Turkey: On The Rebound', Wilson Quarterly, Vol. 6, No. 5 (1982), p. 125.

${ }^{41}$ See, G. E. Gruen, 'Turkey's Relations with Israel and Its Arab Neighbours', Middle East Review, Vol. 17, No. 3 (1985), p. 38. 
different governments. This eventually had a spill-over effect on foreign policy, as well as domestic policies, an area which hitherto governments had tended to leave to experts and foreign ministry bureaucrats.

Equipped with strong powers and charismatic leadership, president Ozal, for example, was able to canalise Turkey's external relations towards realization of his 'vision'. Although Ozal's successors, Demirel and then Sezer, have used their powers with more restraint than their predecessor, the powers and the institutional structure for forceful presidential domination over Turkish politics, both domestic and external, are there for future aspirants. Therefore this aspect of Turkish politics should be kept in mind when considering Turkey's future foreign policy moves. These powers would enable presidents with a political background and strong convictions about the country's place in the world to impose their 'vision' on the foreign ministry, possibly against what the latter considered as the 'national interests' of the country. Since obtaining a consensus on what constitutes the 'national interest' of a country is a difficult, if not impossible, task, this aspect of Turkish politics, with its foreign policy overtures, could create tensions within the decisionmaking bodies of the country and among public opinion in general, as seen during the Gulf Crisis of 1990-1991.42

In a country like Turkey where the military normally plays larger role in determining what is in the 'national interest' of the country than in liberal democracies, a clash between the opinions of the executive and the General Staff always carries dangers of another possible attempt to dislodge those who opposed the military's vision. Although it has been argued above that the Turkey of the 1990s and after is much different from earlier periods, and in this context another outright military intervention in Turkish politics is highly improbable, it can not be entirely disregarded that the possibility is still there and one can conceive various possible future scenarios where the military might find it extremely difficult to resist

\footnotetext{
${ }^{42}$ For Turkey's policies during the Gulf War, see, M. Aydin, Ten Years After; Turkey's Gulf Policy (1990-1991) Revisited, Ankara Paper 4 (London, 2002).
} 
intervention. ${ }^{43}$ Of course, which direction Turkish foreign policy might be forced to take if that was to occur, and what would be the external reactions to such an event, which would eventually have an important effect on Turkish foreign policy, could be difficult to predict. However, if the past is in any way indicative of the future, it could be argued that yet another military intervention in Turkey, even if it was to keep unitary, secular and pro-western Turkey intact within the western political system, could have devastating affects on Turkey's European relations and its leaders might, ironically, end up severing Turkey's western connections (if she had not already been forced out) because of the impossibility of sustaining them in the face of mounting criticisms and extreme pressures from Europe.

It is also stated above that changes in balance of power within the policy-making body can affect a country's foreign policy. In connection with this, the dominance of the military within the political system during the 1980s affected both the foreign policy thinking and actions of Turkey. Later, the inclusion of hitherto obstructed Islamic forces into the realm of decision-making bodies smoothed, if not directly called for, Turkey's openings towards the Middle Eastern Islamic countries. Finally, the economy-driven administrations of Ozal after 1983, also led to the 'economy first' principle in foreign relations, and various political and ideological

${ }^{43} \mathrm{~A}$ hypothetical situation can be imagined where a break-up of the unitary Turkish state might seem imminent because of a Kurdish uprising in the south-eastern Turkey, or in an Algerian-type situation where the secular outlook of the country is threatened because of a takeover of power by radical Islamic forces, that the military might consider it as its 'duty' again to 'save the nation'. For example, when Islamic Refah Partisi, in coalition with Dogru Yol Partisi, came to the power in June 1996, the political atmosphere in Turkey became unbearable within few months as the Kemalist civilian and military elites came to a loggerhead with the government over its ostensibly pro-Islamic polities, that brought country into a severe political crisis and to the brink of yet another coup. At the end, a 'post-modern coup' took place, and the top bras, acting within the National Security Council, and in cooperation with opinion makers in the country, forced the government to resign on February 28, 1997, with a carefully managed public campaign and the establishment of a new coalition between centre-right Anavatan Partisi and centre-left Demokratik Sol Parti. 
differences in international arena were disregarded for expected economic benefits. Of course, the most telling change in the balance of power within the policy-making system during the 1980s was the gradual concentration of powers in the hands of late president Turgut Ozal, which was strongly resisted and opposed by traditional foreign policy elite.

\section{ECONOMIC DEVELOPMENT AND RISE OF ETHNO- RELIGIOUS IDENTITIES}

\section{In Theory}

The socio-economic conditions of a country, closely connected with its political evolvement, form an important factor of foreign policy. The standard of living, the distribution of income, and the social structure related to the facts of production and consumption are elements of social strength or weakness, while political institutions, civil rights, are political stability are measure of political vigour, and both are closely interwoven.

The degree to which the economy of a state has developed may have important consequences for its foreign policy as different states at different levels of developments have different needs and therefore different links to their environments. ${ }^{44}$ In addition, the level of economic development greatly contributes to the internal demands from governments to formulate external policies that reflect and serve the diversity of interests that it produces. ${ }^{45}$ Moreover, the level of economic development may also be effective in determining a nation's capability to implement foreign policy plans. ${ }^{46}$ 'The more a country is develop, the larger is the proportion of its GDP that is likely to be devoted to external purposes, whether these be military

\footnotetext{
${ }^{44}$ Rosenau, in Rosenau/Thompson/Boyds, op. cit., p. 20.

${ }^{45}$ Ibid.

${ }^{46}$ H. J. Morgenthau, Politics Among Nations: The Struggle for Power and Peace, Brief ed., revised by K. W. Thompson (New York, 1993), pp. 133134.
} 
ventures, economic aid programs, or extensive diplomatic commitments'. 47

The cultural and socio-psychological factors, which also belong to this group, are possibly the most difficult to analyze in precise terms. However evasive this factor is, it still exists and perhaps even more enduring than those associated with economic development. No statesmen make decisions in foreign politics without evaluating a pattern of political behaviour of a nation which is either his partner or adversary. ${ }^{48}$ Foreign policy, whether for cooperation or conflict, sooner or later becomes a social process. Patterns of political behaviour, or of general cultural patterns are thus paramount, and statesmen usually base their decisions on their own and historical experiences. Moreover, values and memories may be shared widely within the country, thus producing a bounding effect between people, or they can be divisive forces among different parts of the society. Obviously, the societal unity may have important effects on the formulation of the country's foreign policy and the conduct of its external affairs. ${ }^{49}$

Foreign policy formation, and its effectiveness once formulated clearly depends on many factors, but the extent of the support which officials would get from people is one of them. Furthermore, the importance of social and cultural unity as foreign policy input could be observed from the many nation-states which are affected by internal dissension among different groups. Though the implications of this fragmentation for the conduct of foreign policy are not easily discernible, its importance for Turkey, which was almost thorn apart by ideological strife during the 1970s and came to be affected by an ethnic separatism during the 1980 s, is quite clear.

The characteristics and personality of decision-makers may have affects on their decisions, and therefore on a country's foreign policy. The office gives the decision-maker certain responsibility for making objective decisions when confronted with objective

\footnotetext{
${ }^{47}$ Rosenau, in Rosenau/Thompson/Boyds, op. cit., p. 20.

${ }^{48}$ Gros, op. cit., p. 119.

${ }^{49}$ Rosenau, in Rosenau/Thompson/Boyds, op. cit., p. 21; Morgenthau, op. cit., pp. 149-150.
} 
situations, but whether he actually makes those decisions may depend on his 'decisiveness'. Equally, the office gives him certain powers, but whether he enlarges the power of the office may depend on his 'assertiveness'. ${ }^{50}$ The objective situation would obviously influence the decisions of any man, but his personal views of national interest and his own personal interests and his personal style would also shape the decision. Therefore, it should be remembered that personality of decision-makers is an important determinant of nation's foreign policy, and 'the higher in the hierarchy of the foreign policy organization an individual's role is, the more likely are his personal characteristics to affect foreign policy decisions'. ${ }^{51}$

Apart from personal expedience, ideological inclinations and societal pressures, man's values are formed, in part, by his religious beliefs. Therefore, it is also relevant to our assessment that the role of religion, in Turkish case Islam, in foreign policy-making should be considered, especially since Islam, unlike Christianity, does not prescribe the separation of religion from politics. ${ }^{52}$ Indeed, devout Muslims argue that Islam is a complete social, political, legal and cultural system, and has its law: the Sharia. Consequently, Sharia is the only legitimate rule and there can be no separation between politics and religion. The importance of Islam's influence on foreign policy of Moslem countries, therefore, should to be considered. As an influence, 'it can act (...) as an integrative force, creating consensus on foreign policy objectives...[providing] l'esprit de corps...to a population, and...mobilizing external sources in support of state....In other cases, Islam can be constraint on policy'.53 According to Dawisha, an important problem which foreign policy analysts face all too frequently when trying to uncover the effect of Islam on specific foreign policy actions, is the question of whether 'a particular policy

${ }^{50}$ J. de Rivera, Psychological Dimension of Foreign Policy (Columbus, Ohio, 1968), p. 165.

${ }^{51}$ M. G. Herman, 'Leader Personality and Foreign Policy Behaviour' in J. N. Rosenau (ed.), Comparing Foreign Policies: Theories, Findings, and Methods (New York, London, 1974), p. 202.

${ }^{52}$ For a comparative discussion of Islam's place in determining foreign policy mainly in the Middle Eastern/ Arab context see A. Dawisha (ed.), Islam in Foreign Policy (London, 1983).

${ }^{53}$ Ibid., p. 4. 
pronouncement or decision motivated by Islam, or was it motivated by some other value or consideration... whereby Islam would be used to simply to bestow credibility and legitimacy on the policy'. ${ }^{54}$ This also clearly relates to the Turkish case.

\section{In Practice}

It was clear during the 1980s that Turkey's international affinities affected its economic policies. Especially, Turkey's move towards a liberal economy in early 1980's had much to do with its linkages with, and aspirations to be part of, the western political system. ${ }^{55}$ Turkey's partnership in the western political system and its essential contribution to western security interests provided it with much more foreign aid and help during its economic transition than any other country that tried to do the same thing. ${ }^{56}$ Therefore there came into existence yet another linkage between Turkey and its western vocation through its transition in 1980s to liberal economy.

Once Turkey made its switch, its new liberal economic system demanded a certain set of political actions and international connections. The common attribute of the programme that introduced the liberal economy to Turkey on 24 January 1980, and other austerity programs introduced since than with the backing of IMF and the World Bank for the recovery of the Turkish economy, is that they all necessitated massive net foreign currency inflows. The ways to generate the necessary amount included heavy borrowing from abroad, persuading foreigners to invest in Turkey, and increasing and diversifying Turkey's export potentials. However, the crucial point to all the economic measures aimed at obtaining the above mentioned results was that they all, in one way or another, depended on the willingness of other countries to respond in a way that would favour

${ }^{54}$ Ibid., p. 5.

${ }^{55}$ This linkage was analyzed in Aydin, Foreign Policy Formation, 'Chp. 7: Foreign Policy and the Revitalisation of Turkish Economy'.

${ }^{56}$ For a comparision between foreign aid figures to Turkey and to Argentina and Mexico in the same period and their connection to political reasons, see, S. Hewin and R. O'Brien, et.al., Turkey's International Role (London, 1988), p.110. 
Turkey. Since it is clear that the success of the programme depend largely on the availability of foreign assistance, it can easily be imagined how Turkish foreign diplomacy had to exert itself to maintain contact with the various assisting governments and organizations

Therefore, both during the 1980s, as the Turkish economy progressively integrated with the world economy, and during the 1990s, while it became part of global economics, the foreign policy became increasingly concerned with obtaining necessary foreign loans, opening up necessary markets for Turkish goods, and striking necessary deals with foreign governments and sometimes even with companies in order to bring more investments into the country. Thus, as the foreign policy of the country needed to be in tune with its economic programmes, economic necessities also became an important variable of Turkish foreign policy making. As a result, as Turkey's need for fresh markets was growing in the 1980s, so its political efforts to find openings in the Middle East and Eastern Block also increased. However, at the same time, realization of the fact that the considerable sums needed by the Turkish economy could come only from western sources demanded a continuation of Turkey's western linkages. Any severing in political relations would have dealt a blow to its economic transformation as well.

On the social side, too, Turkey had experienced important changes during the 1980s. The repression of the liberal and left-wing intelligentsia by the military regime, and also their efforts to promote orthodox Islam as an antidote to extremism in society, led to perhaps not totally unexpected, but unforeseen, result of growing visibility of Islam in Turkish society, which was also effected by the world-wide Islamic revival.

Although many high level and influential Motherland Party members were branded as 'Islamist', at least partial to Islam, by the secular Turkish intelligentsia, it is difficult to find particular instances during the 1980s where they used their influence to get (and obtained) policy changes in foreign relations. Giving allowance to the difficulty of separating the possible influence of Islam from other motivating values, and also of distinguishing between Islam's motivating and/or justifying roles, a possible explanation for this subdued role of the 'Islamists' within the Motherland Party, could be 
that the 'Islamic faction' of the party was pre-occupied most of the time with a power struggle against the 'nationalist' and 'liberal' factions, and, at the same time, the leader of the party, Turgut Özal, who controlled the party completely, had strong foreign policy ideas of his own and thus, thanks to his delicate balancing between various factions of the party, did not allow any one faction to dictate his policy-making. Moreover, most of the time, the presence of everwatchful President Evren against 'Islamic' manifestations within Turkish politics, was also a restraining factor for Islamic influences on foreign policy.

As a result, the Islamic revival within the country did not particularly affected Turkey's foreign policy-making during the 1980s - provided that there was a desire and pressure for change from the 'Islamists' since this is, save sporadic demands for closer relations with the Islamic countries, also difficult to pin down. Therefore, one of the actions that the Islamists were supposed to oppose strongly, that is Turkish application to the EC membership, went smoothly in 1987 without significant opposition.

However, since 1989, the effects of the Islamic affinities, in connection with the ethnic and historic sentiments, seemed on the rise. Yet again, it was still very difficult to ascertain whether the Turkish public's outcries regarding the Karabakh and Bosnian conflicts were the results of Islamic connections, or rather originated from what was perceived, by public at large, as attempts to wipe out Turkish ethnic brethren in the east and Ottoman legacy in the west. It is rather safe to argue that the role of Islam in Turkish foreign policy during the period under consideration was mostly confined to the justification of the policies for which the government opted for other reasons, and Turkey's reorientation towards the Middle East during the 1980s was the result of a combination of factors, among which the Islamic revival occupied a small part - as indicated by the fact that Turkey turned towards the Western Europe and the Soviet Union (later on former Soviet Republics) when the political and economic incentives for closer cooperation with the Middle East declined after 1985.

This discussion brings us to the question of the public's role in the making of Turkish foreign policy during the 1980s. All the channels of public expression were ruthlessly suppressed under the 
military regime (1980-1983) to the point that the public opinion's role in foreign policy-making was minimal. It's affects, if there was any, during this period was only indirect in that the military regime was anxious to keep the public on its side. Thus the military leaders might have taken decisions, which, they thought, would go well with the public, although, due to nature of the regime, there was no apparent domestic pressure on the military government.

Even after the return of the civilian government, the recovery of public opinion's freedom for expression was slow as a result of various restrictions formulated by the new constitution and other related laws. Under the new laws, the activities of the various groupings, through which public opinion could be related to the government, were restricted to non-political areas, which by definition also excluded the foreign policy-making. Thus, during most of the period under consideration the governments got an 'easy-ride' in foreign policy-making as far as the public pressure concerned. However, as Turkish public opinion became a progressively important factor in the policy-making process, paralleling the increasing democratisation of society especially after 1989, the Turkish governments had to resist particularly strong pressures over its policies towards the Karabakh and Bosnian conflicts.

From the government's point of view, both of these conflicts represented no-win situations. As far as the Karabakh conflict concerned, Turkish public opinion sided heavily with Azerbaijan, and the government was under pressure not to sit on the sidelines so long as the fighting continued. Non-intervention by Turkey only stirred up public opinion and also gave Iran an opportunity to steal the lead from Turkey and play protector to Azerbaijan. Intervention, on the other hand, would have been extremely costly for Turkey in its future relations in the Caucasus, and with Russia and the US. Hence, in its official approach to the conflict in Nagorno-Karabakh, the government faced difficult policy choices between domestic pressures, stemming from the sympathy of the Turkish public for the Azeris, who they regarded as victims of Armenian aggression, and its desire to remain neutral and play a moderating role. Moreover, the complacency with which Armenian military advances had been received in the West did not help the severely embarrassed government, which was not only pro-Western but did its best to remain on good terms with Armenia as well as Azerbaijan. Thus, this 
conflict firmly underscored the dilemma that would face Turkey in its efforts to maintain strict neutrality regarding ethnic conflicts in the former Soviet republics.

Moving along from the Caucasus to the Balkans, another manifestation of growing nationalism in world politics after the end of the Cold War, that is struggle between Serb, Croat and Moslem forces over Bosnian territories, aroused great interest in Turkish public. Though Bosnia is several hundred miles from Turkey's borders and the Bosnian Moslems are not ethnic Turks, it seemed that Turkish public opinion had developed a feeling of kinship and responsibility for the Muslims left behind by the retreating Ottoman Empire from the Balkans after around five hundred years of domination. ${ }^{57}$ Moreover, the existence of substantial numbers of 'Boshnaks', Turkish citizens of Bosnian origin, about four to five million, in Turkey further increased the identification of Turkish people with the Bosnian Moslems.

What was important for Turkish foreign policy-making was that the importance of religious and historical links, alongside ethnic bonds, seemed to be on the rise in the country, ${ }^{58}$ and the Turkish government, as in the conflict between Armenia and Azerbaijan, was caught between domestic pressure and what was considered by decision-makers as sensible and responsible policy. Thus, while the Turkish government in its official response to these crises tried to be extremely restrained and followed policies aimed at creating coordinated responses with other states through international organizations, such as the UN, NATO, the OSCE and the ICO, in order to avoid charges that Turkey was pursuing pan-Ottomanist policies in its neighbourhood, Turkish public opinion, increasingly frustrated by the inactivity of the West, became very critical of what they perceived as the passivity of their government.

\footnotetext{
${ }^{57} \mathrm{For}$ an analysis of the Turkish policies in the Balkans at the time, see the G. Winrow, Where East Meets West; Turkey and the Balkans, Institute for European Defence and Strategic Studies, European Security Study No. 18 (London, 1993).

${ }^{58}$ Ibid., p. 25.
} 
Moreover, there were wider and in the longer-term more important aspects of these conflicts for Turkish foreign policy. Most notably, a reassessment among the vast majority of Turkish people about the 'real face' of the 'western values' and the place of Turkey vis-à-vis the West took place. Especially in connection with the Bosnian conflict, while the Western inactivity towards Serbian aggression was increasingly interpreted as 'Western complacency' towards Serbian atrocities, questions were raised about whether the West would have allowed the Serbs to conduct their so-called 'ethnic cleansing' if the victims were Slovenians or Croatians, that is Christians instead of Moslems. Thus speculations that Serbian attacks were in fact part of a new 'crusade' aimed at expelling the last remnants of the Ottomans from Europe were also aired. These events in the Balkans, when viewed together with the Karabakh issue, where as mentioned earlier Turkish public opinion again saw a Christian solidarity against Moslem Azerbaijanis, resulted in the questioning of both Turkey's Western orientation and the desirability of its further integration with Europe. In the meantime, pan-Turkist and neoOttomanist ideas made way among at least right-leaning intellectuals. ${ }^{59}$ Although these discussions did eventually die down without actually leading Turkey to different paths, they, coupled with the frustration felt as a result of continual 'European rejection' of Turkey, put the successive coalition governments under the public pressure, and lead to a process of yet another reassessment of Turkish identity in the early 1990s.

\section{EXTERNAL ENVIRONMENT: SYSTEMIC CHANGES and TURKISH FOREIGN POLICY}

\section{In Theory}

Unlike in domestic politics, where the political leadership exercise relative control in foreign policy political decisions are aimed at an environment over which political leaders (especially from smaller powers) have very little, if any, control. On the other hand, although, in practice, the conduct of states in the international arena

${ }^{59}$ For representative examples of such views see the special issues of Turkiye Gunlugu, No. 19 (Summer 1992) and No. 20 (Autumn 1992). 
seems to be constrained only "by the decisions of the states themselves, not by an authority external to them', ${ }^{60}$ thus the basic feature of international society appears to be its 'anarchical nature', ${ }^{61}$ foreign policies are not made in vacuum but in relation to other bodies similarly acting in the global arena, which creates certain sets of restraints, 'be it conventional, customary, ethical, legal or institutional'. ${ }^{62}$ As foreign policy consists of 'decisions and actions which involve to some appreciable extent relations between one state and others', ${ }^{63}$ it can be defined as 'the actions of a state toward the external environment and the conditions under which these actions formulated' ${ }^{64}$ Therefore, while formulating foreign policies, policymakers have to take their international environment into account, since the success in achieving their goals may be affected by other states' responses and the level of their accurate reckoning of others' policies. Moreover, the structure of the international political system and the geo-political position of the state vis-a-vis the international system are also important determinants of a country's foreign policy and its success. ${ }^{65}$

The more an association is valued, the more it imposes constraints on its members, and the degree of influence members of an association can exert over each other depends upon the relative priorities they attach to maintenance of the association and of membership in it. ${ }^{66}$ This effect could be observed on Turkey's

${ }^{60}$ Reynolds, op. cit., pp. 9-10.

${ }^{61} \mathrm{H}$. Bull, The Anarchical Society: A Study of Order in World Politics (London, 1977).

${ }^{62}$ Reynolds, op. cit., p. 97.

${ }^{63}$ J. Frankel, The Making of Foreign Policy: An Analysis of Decision-Making (London, 1963), p. 1. Same explanation was also offered by B. White, 'Analysing Foreign Policy: Problems and Approaches' in W. Clarke and B. White, An Introduction to Foreign policy Analysis: The Foreign Policy Systems (Ormskirk, 1981), p. 1.

${ }^{64}$ K. J. Holsti, International Politics: A Framework for Analysis (Englewood Cliffs, 1972), p. 21.

${ }^{65} \mathrm{P}$. E: Dougherty and R. L. Pfatzgraff, 'The Role of Environment in International Relations' in J. Barber and M. Smith (eds.), The Nature of Foreign Policy (Edinburg, 1974), pp. 87-88.

${ }^{66}$ Reynolds, op. cit., pp. 102-103. 
relation with the Council of Europe and the European Community during the period under consideration.

Obviously, a major part of the external environment of decision-makers is formed by the actions of the other governments in international arena. Since all the governments act in order to further their own interests, a competition and/or conflict between states is the natural outcome. However, the nature of the relationship (dependent, inter-dependent, oppositional, etc.), will also be affected in the first place 'by the extent to which the two governments feel they need to the support of the other in question' ${ }^{67}$ In this context, an important part of the effects from the international environment is brought upon states by their linkage and influence relationships with other states and state groupings. ${ }^{68}$ The essential variables which affect the exercise of influence have been identified as: (1) 'the amount of influence a state wields over others can be related to the capabilities mobilized in support of specific foreign policy objectives'; ${ }^{69}$ (2) the 'extend to which there are needs between the two countries'; $;{ }^{70}$ (3) 'the ephemeral quality of responsiveness'; ${ }^{71}$ (4) the maximum utility of the resources available; ${ }^{72}$ and (5) the probability of reactions. ${ }^{73}$

However, this approach should be treated carefully when studying Turkey during the 1980s, since after experiencing US embargo following its 1974 Cyprus intervention and attempts by the US to use its influence patterns extensively on Turkey to obtain a certain set of outcomes which were not favoured by it, Turkey

\footnotetext{
${ }^{67}$ Ibid., pp. 114-115.

${ }^{68}$ The affects of Turkey's influence relationship with the US in regard to Turkey's Cyprus policy is discussed by S. Bolukbasi, The Superpowers and the Third World: Turkish-American Relations and Cyprus (New York, London, 1988).

${ }^{69}$ Holsti, International Politics: A Framework for Analysis, p. 149.

${ }^{70}$ Ibid., p. 151.

${ }^{71}$ Ibid., p. 153.

${ }^{72}$ R. Dahl, Modern Political Analysis (Englewood Cliffs, 1976), p. 33. Cited in Bolukbasi, op. cit., p. 6.

${ }^{73}$ D. Singer, 'Inter-Nation Influence: A Formal Model' in J. N. Rosenau (ed.) International Politics and Foreign Policy: A Reader in Research and Theory (New York, 1961), p. 386.
} 
became much more restive in its relations with other states and much more sensitive towards any influence attempt or intervention. Moreover, the apparent failure of US influence attempts during the second half of the 1970s made Turkey an unlikely target for new attempts during the 1980 s, though there were European attempts to affect the outcome of Turkey's democratization process; they are treated in this paper as a result of Turkey's conscious linkages with Europe rather than influence relationship.

\section{In Practice}

The importance of the external environment, especially regarding European reactions to the military coup and the subsequent evolution of Turkish democracy, are already elaborated above. Towards the end of the period under consideration, another impetus for change, originating in the external environment, came to dominate Turkish foreign policy-making and forced Turkey to reconsider its place and standing in the world. This was the transformation of Eastern Europe and the dismemberment of the Soviet Union, which had enormous impacts on both Turkish foreign and security policies.

It has been argued 'perhaps no other country outside the former Soviet block has seen its strategic position more radically transformed by the end of the Cold War than Turkey'. ${ }^{74}$ Throughout the Cold War, as mentioned earlier, Turkey was a distant outpost on the European periphery, a barrier to Soviet ambitions in the Middle East, and a contributor to the security of Europe. Turkey's geo-strategic 'value' was largely limited to its role within the Atlantic Alliance and, more narrowly, its place within NATO's southern flank. By the end of the Cold War, however, all these were altered by the appearance of new zones of conflict on three sides of Turkey. Further, the emergence of six independent Muslim states to the

${ }^{74} \mathrm{E}$. Mortimer, 'Active in a New World Role' in Turkey, Europe's Rising Star; The Opportunities in Anglo-Turkish Relations, published for the Turkish Embassy, London by Lowe Bell Communications (London, 1993), p. 44. Following analysis is largely drawn from Mustafa Aydin, 'Between Euphoria and Realpolitik: Turkish Policy toward Central Asia and the Caucasus' in T. Ismael and M. Aydin (eds.) Turkish Foreign Policy in the $21^{\text {st }}$ Century; A Changing Role in World Politics (Aldershot, 2003). 
northeast opened Turkey's eyes to a vast territory inhabited by some 150 million fellow Muslim Turkic-speakers. The years of claustrophobia suddenly ended, and under the prevailing atmosphere of subsequent euphoria, Turkey's common cultural, linguistic, and religious bonds with the newly independent Central Asian and Caucasian republics were frequently mentioned. Turkey was also seen, both inside and outside, as an economic and political model for these new states. Even limited pan-Turkist ideas were circulated freely. ${ }^{75}$

On the other hand, having based its whole post-war foreign and security policies on the strategic importance for the West of its location vis-à-vis the Soviet Union, Turkey, initially hardly welcomed the end of the Cold War. As the relevance of NATO in the "new world order' was opened up to discussion, especially by the western Europeans, Turkey suddenly found itself in a situation where it was threatened both by the lingering uncertainties regarding its immediate neighbourhood and by the fact that its western security connection, the anchor of its European vocation, was fundamentally damaged by the end of the Cold War, which hitherto provided a relative safety and stability in the region. The realization that Turkey may face military threats virtually all around and it may not be possible to evoke the western security umbrella for protection shook the very foundations of Turkish security thinking and policy, and the need to reassess its post-Cold War situation vis-à-vis potential threats was alarmingly expressed at the highest levels.

At the same time, Turkey has always attributed utmost importance to stability and continuity in its neighbourhood, and has been sensitive against to changes in the existing equilibrium within its surrounding region to the extent that the preservation of the current balance is usually considered as part of the Turkish national interest. In this context, the disintegration of the Soviet Union affected both Turkey's foreign and security polices. In a similar pattern, Iran-Iraq and the Gulf wars in the Middle East, Bosnia-Herzegovina and Kosova crises in the Balkans, and the conflicts over Nagorno-

${ }^{75}$ Turkey's policies towards Central Asia and the Caucasus were discussed fully in M. Aydin, 'Kafkasya ve Orta Asya'yla Iliskiler', B. Oran (ed.), Turk Dis Politikasl; Kurtulus Savasindan Bugune Olgular, Belgeler, Yorumlar, Vol. 2 (Istanbul, 2001), pp. 366-439. 
Karabakh, Chechnya and Abkhazia in the Caucasus, all took place within the immediate vicinity of the country and presented Turkey with the dangers of involvement into such regional conflicts that did not represent immediate threats to its borders.

Turkey traditionally avoided involvement in regional politics and conflicts. However, international developments, as well as the evolution of Turkish domestic policies, compelled it during the 1990s to concern itself more with regional events, and to attempt for a prominence in international politics and a higher profile in the Middle East and Muslim/Turkic areas of the former Soviet Union. It was thus drawn into the volatile politics within the Caucasus (especially Nagorno-Karabakh conflict), the Balkans (Bosnia-Herzegovina and Kosova), and the Middle East (Kuwait-Northern Iraq), where she was forced to take sides and follow an 'active' foreign policy. Dramatic changes in Turkey's traditional policy of isolationism from regional conflicts and its increasing active participation in regional issues have, on the one hand, provided it with the potential to fulfil its economic and political expectations, while on the other hand, also brought about new challenges and security problems.

But almost a decade before all these challenges came about, the September 12, 1980 coup d'etat had already have a deteriorating effect on Turkish-European relations. Although the military regime from the beginning declared its distinctly pro-western attitude, the incompatibility of military dictatorship with the liberal democratic tradition of the West, coupled with the slight willingness on the European side to show an understanding of Turkey's political problems, resulted in widespread European criticism and strained relations. Consequently, Turkey's relations especially with the European representative institutions, such as the Council of Europe and the European Parliament, suffered considerably. Moreover, European organizations, and also governments as well, attempted to use their political and economic leverage on Turkey to obtain an early return to democracy and improvements in human rights conditions in Turkey. Although these attempts were partly successful because of Turkey's receptiveness towards such pressures as a result of its European vocation, they also created counter-reactions among the Turks as they resented being subjected to foreign pressure. 
During the military regime (1980-1983), Turkish-American relations, however, expanded as the latter, in contrast to the Europeans, showed an understanding towards Turkish problems mainly because of its strategic considerations. Thus, in the atmosphere of renewed Cold War, American military and economic aid to Turkey increased and a relatively unproblematic period of Turkish-American relations developed. Strategic considerations and further rapprochement in Turkish-American relations were also instrumental in Turkey's conciliatory attitude in the Aegean where Turkish interests clashed with those of Greece. As a result, the normal flight conditions were allowed to resume in the Aegean air space and, after a personal 'promise' from NATO Secretary-General General Bernard Rogers to General Evren, Turkey dropped its objections to Greece's reintegration into NATO structures. However, this initial conciliatory attitude by Turkey did not result in further normalization of Turkish-Greek relations as the Pan Hellenic Socialist Party of A. Papandreou came to power in Greece in 1981 with an anti-Turkish rhetoric and propaganda.

During the same period Turkey's political contacts with Moslem and Communist countries also increased as the former needed new outlets and political allies in the face of mounting criticism and increasing alienation from Europe. The latter's largely uncritical attitude towards the military regime greatly facilitated these contacts. Moreover, adoption of a liberal economic strategy based on export-led growth demanded new markets and large foreign inflows. Given the fact that the political standstill in Turkish-European relations further hindered Turkey's efforts to rally any concerted European effort to help its economic recovery, Turkey had to turn increasingly to US-dominated international monetary organizations for necessary foreign aid, and to the Middle East and former Eastern Block for new export markets. Furthermore, the Iran-Iraq war, towards which Turkey took a neutral stand, was largely instrumental in new economic surge towards the Middle East as both countries were forced by the war to rely increasingly on Turkey for their necessary supplies and connections with the West via Turkish territory.

Although the gradual return to Turkish parliamentary politics from 1983 onwards should have ideally provided a base for normalization of Turkish-European relations, the reality differed as 
European criticism continued to focus on the deficiencies of the Turkish political system and persisting practices of torture and other human rights abuses. Consequently Turkish-European political relations were slow to recover, despite the willingness and various attempts of consecutive Ozal governments. Towards the end of the decade, paralleling its democratisation process, Turkey had gained most of the lost ground in its relations with the European states and institutions. Yet further progress beyond that point proved impossible, and the Turkish application for full EC membership was refused in 1989 not only in consideration of Turkey's economic deficiencies, but also its political shortcomings and alleged 'cultural differences'. This in turn created a new wave of resentment within Turkey and brought about questions over the sustainability, and indeed the desirability, of existing patterns of relations between Turkey and Europe.

Turkish-European economic relations, on the other hand, recovered from their lowest point during the military regime, despite the inability of Turkey to obtain further concessions from the Community for its exports, especially for textile products, and release of the fourth financial protocol of the EC mainly because of Greek objections. In this recovery, the end of the Iran-Iraq war and the decreased purchasing power of Middle Eastern countries as the oil prices declined after 1985 played an important part since the decline in the Middle Eastern market forced Turkey to turn to its traditional European markets. Of course, gradual relaxation of political tension also played an important role.

Turkish-Greek relations continued to be strained during the period, despite various overtures from both sides for normalization of relations, and in March 1987 reached a point of almost open military conflict over the Aegean Continental shelf. This resulted in consecutive meetings of prime ministers and foreign ministers of the two countries and relations moved to a strained but contained stalemate. The declaration of independence by the Turkish Republic of Northern Cyprus in December 1983 was particularly instrumental in earlier worsening of relations. Moreover, constant Greek attempts, after its membership to the $\mathrm{EC}$, to make the Community a party to Turkish-Greek disputes and its continuing blocking of the normalization of Turkish-Community relations also created tensions between the two countries. 
Turkish-Middle Eastern relations, on the other hand, continued to develop during the Ozal governments despite the fact that part of the economic incentive for closer relations disappeared gradually after 1985. In continuation of improved relations, important roles played by the growing ideological and cultural affinities of the ruling political elite with these countries and by the insistence of Ozal to open up Turkish foreign policy towards new centres. Moreover, especially in Turkish-Iraqi relations, the perceived common security threat from Kurdish separatists was a source for closer relations. However, especially towards the end of the decade, and certainly after the end of the Iran-Iraq war, relations with Iraq, and also with Syria, were strained because of the dispute over sharing the waters of Euphrates and Tigris rivers. The issues became so explosive in the region that it was referred as a possible source of the next Middle Eastern war.

However, 'the next war' in the Middle East erupted between Iraq and the US-led coalition forces over Kuwait. Turkey's policies during the crisis, both showed deviations from its established Middle Eastern foreign policy patterns and presented important clues about its post-cold war foreign policy stand. Turkey's Gulf policy, which was marked by active involvement in contrast to earlier Turkish stand of not getting drawn into Middle Eastern affairs, was heavily determined by president Ozal, and as such represented part of his 'vision' for Turkey's future role in regional and international politics. In the process, however, he precipitated a vigorous debate within Turkey over his role as president and the extent of his authority.

Turkish-American relations continued to enjoy cooperation after the return of the civilian government, again heavily influenced by Turgut Ozal, who concluded that the US was undisputed leader of the world and that Turkey should closely associate itself with the US in international politics in order to attain its deserved place in the world, if not to prevent US influence from harming Turkish interests. Moreover, friendship between two presidents (Ozal and Bush) introduced a personal touch into the Turkish-American relations, and strategic cooperation reached its peak during the Gulf War when Turkey supported the American stand against Iraq. However, after the war, as the governments in both countries changed, relations between the two countries somewhat cooled down. 
Turkish-Soviet (and later Russian) relations, also, continued to improve during the second half of 1980 s and important cooperation especially in the economic realm came into existence. In this context, Turkey's innovative attempt to bring together those countries bordering directly the Black Sea or neighbouring them in the Black Sea Economic Cooperation organization was also instrumental.

\section{CONCLUSION}

During the 1980s, change in Turkish foreign policy came about because changes in Turkey's domestic political, economic, and social structures, as well as its international environment. In this context, the affects of the European criticism and aloofness from Turkey were particularly important in forcing Turkey to search for alternatives in its foreign relations. Thus, Turkey of 1980s followed a foreign policy, designed to balance its foreign policy between disappointments and rebukes from Europe and its new openings towards the Middle East, former Eastern European countries and the Soviet Union. At the end of the decade, Central Asian and Caucasian countries were added to these as the Soviet Union was rapidly dissolving.

The most important determinants of Turkish foreign policy during the military regime were the heightened strategic considerations as a result of the renewal of the Cold War; the necessities and demands generated by the revitalization of the national economy; and the nature of the political system in Turkey that largely conditioned Turkey's European connections. The military government simply try to preserve Turkey's traditional connections, while attempting, but failing, to shield its domestic politics from external scrutiny. Conversely, Turkey became much more open to international influence and criticism in the same period, because of its chosen economic policy and avowed desire to become full member of the EC. Thus, Turkey's international politics and economic relations were internationalized during the early 1980 s, effects of which came to dominate Turkey's external relations at the end of the Cold War.

Second part of the 1980s in Turkey was dominated internally by a gradual return to democratic governing, and internally by the attempts of the successive Ozal governments to claim back Turkey's 
place among European states. Problematic nature of Turkish-Greek and Turkish-European relations as well as changing character of the international system towards the end of the decade also help to set the scene for Turkey's post-Cold War posture. Besides, second part of 1980s witnessed in Turkey discussions over Turkish identity, particularly ethnic and religious aspects, and their role in determining Turkish foreign policy as well as domestic politics. While the growing ethnic radicalism in south-eastern Turkey in this period and its international connections created inhibitions for Turkish foreign policy, growing awareness at the same period of Turkey's military power posture allowed it to exercise with the precursors of the idea of "Turkey as a regional power", which came to dominate Turkish foreign policy thinking in the early 1990s.

Finally, as set in the introduction of this paper, Turkey of 1980s was clearly dominated by a tendency to "change", sometimes intentionally sometimes with outside pressures, the every aspect of the country from its economic and political structures to peoples' identities and believes. Among all the intention and actual preference for change in other aspects, country's decision makers nevertheless tried to preserve fundamental parameters of Turkey's foreign policy during the period under consideration. At the end, it was the culmination of domestic and international pressures, as well as the rapidly changing nature of the world politics at the threshold of the post-Cold War era that forced Turkey to move away from its traditional foreign policy posture during the 1990s. However, the fundamental forces that brought about these changes and reshuffling in the priorities of the Turkish foreign policy and were analysed in this paper, were clearly set during the 1980s. 